\title{
Digital Learning is Obligatory: Factual Tragedy of Absurd Unpreparedness \\ (Invoice of Pandemic Learning)
}

Thobias Sarbunan

\author{
IAKN Ambon/Indonesia
}

t.sarbunan@iaknambon.ac.id

\section{Introduction}

Factual data of learning in pandemic not always as sweet as rich country and modern, as (Bagarukayo \& Kalema, 2015) found that eLearning even transformed to technology that dominated to the teaching and learning, such in case of higher education in South Africa, ended to ineffective utilization approach. Moreover, that scholar stressed that factor affected incapability and inactive to practice technology approach such as "wealth, and have infrastructure shortages, access issues, shortage of skilled instructor, managers' jobs loss misconceptions and instructor difficulty to create content".

In addition, (Arkorful \& Abaidoo, 2014) approved that in applied disadvantage of eLearning to adopt in higher education derived from eight factors such as "learner's struggle of contemplation, remoteness, as well as lack of interaction or relation. Then a method of eLearning was ineffective rather than traditional process. Moreover, for the students were low literacy of technology will irritate to elevate the knowledge skill. Besides, eLearning initiated to the students must use for a proxy but influence cheating behaviour when assessment conducted. In crucial behaviour students were close to plagiarism behave. While in the institution level, the failure probabilities had high risk to adopt and adapt the process of 
eLearning. Additionally, to the field of science was difficult to practice in depth, to the use of eLearning compare to social and humanities field. At the high risk, eLearning needs to the stable financial background rather than poor financial can be a burden to conduct that process".

The other experience from this author (Dignan, 2020) pandemic push all of society included education to run activity but in divided. In education, especially for school process, the obvious gap between good financial teachers and poor financial teacher to accelerate eLearning. While the students side only few were capable to have a good facility for example a pc, but the other were poor facility to learn in eLearning process, included internet connection. Despite, overloaded obligation to run eLearning, it became frustrated to the institution of school to have appropriate facilities. In higher education level, burden catastrophe that affected university learner life for example the problem of saving the extra moneys, further educational program hindered, highest cost to acquire online learning, and problematic of financial budget management to fulfil campus facilities requirement.

According to (Merrill, 2020) "hundreds of teachers, many of them operating in countries where teach-from-home has been in place for weeks, weigh in on the mental approach you need to stay grounded in this difficult time. I can tell you, now that we're in week 7 of online learning, that much of what you will do will be trial and error, " wrote Stacy Rausch Keevan, who was teaching in Hong Kong. "Don't stress about that-it won't do you any good. For my middle school English and humanities classes, I'm offering the same lessons I would normally do live, but in smaller doses".

Hence asserted from (Li \& Lalani, 2020) "the integration of information technology in education will be further accelerated. In addition, online education will eventually become an integral component of school education. While some believe that the unplanned and rapid 
move to online learning - with no training, insufficient bandwidth, and little preparation will result in a poor user experience that is unconducive to sustained growth, others believe that a new hybrid model of education will emerge, with significant benefits". In other fact, [95\% of students] in Switzerland, Norway, and Austria have a computer to use for their schoolwork, only [34\% in Indonesia do] those cases were gap description of the opportunity to reach internet access".

The other shock circumstances as (Li \& Lalani, 2020b) found, "whilst virtually all [15-year-olds] from a privileged background said they had a computer to work on, [nearly $25 \%$ of those from disadvantaged backgrounds] did not, the gap of internet access in USA. Different from New South Wales, Australia, some schools and government were sufficient to digital equipment, but in fact tremendous findings in that area were opposite to sufficient technology facilities, that in short were remained stated in divided factor”.

After the several of previous literatures asserted to the chaos of education in the mid of pandemic, the key point of that barriers was unprepared to the crisis which undergo immediately even to the wide background of countries, societies, also type of education institution. The main point of problem solving to the chaos of pandemic occurred to rethink and analyse all of education system that simultaneously adapt to all situation like pandemic.

\section{Reference}

Arkorful, V., \& Abaidoo, N. (2014). The role of e-learning, the advantages and disadvantages of its adoption in Higher Education. International Journal of Education and Research, 2(12), 397-410. https://www.ijern.com/journal/2014/December-2014/34.pdf

Bagarukayo, E., \& Kalema, B. (2015). Evaluation of elearning usage in South African universities: A critical review. International Journal of Education and Development 
Using Information and Communication Technology (IJEDICT), 11(2), 168-183. Eric. https://files.eric.ed.gov/fulltext/EJ1074146.pdf

Dignan, L. (2020, March 22). Online learning gets its moment due to COVID-19 pandemic: Here's how education will change. ZDNet. https:/www.zdnet.com/article/onlinelearning-gets-its-moment-due-to-covid-19-pandemic-heres-how-education-willchange/

Li, C., \& Lalani, F. (2020, April 29). The COVID-19 pandemic has changed education forever. This is how. World Economic Forum. https://www.weforum.org/agenda/2020/04/coronavirus-education-global-covid19online-digital-learning/

Merrill, S. (2020, March 19). Teaching Through a Pandemic: A Mindset for This Moment. Edutopia. https://www.edutopia.org/article/teaching-through-pandemic-mindsetmoment 